\title{
REPRESENTAÇÕES DA DIMENSÃO DE SAGRADO E DE ESPIRITUALIDADE: O MAR E O SILÊNCIO NAS POÉTICAS DE CECÍLIA MEIRELES, SOPHIA DE MELLO BREYNER ANDRESEN E GLÓRIA DE SANT'ANNA
}

Ana Paula Perdiz de Crato Fogaça

Resumo: Tendo como referentes poéticos o mar e o silêncio e, através abordagem comparatista, este trabalho propõe analisar laços existentes nos versos de três poetas de língua portuguesa: Cecília Meireles, Sophia de Mello Breyner Andresen e Glória de Sant'Anna.

Os diálogos intertextuais da dimensão de sagrado e de espiritualidade potenciada pelos caminhos simbólicos do mar e do silêncio revelam a cumplicidade entre as poetas.

Como fundamento dessas visões dialógicas recorreu-se às teses do teórico Michel Collot sobre referente poético; à conceção fenomenológica de Gaston Bachelard sobre a imaginação material e dinâmica da(s) água(s), e às interpretações de Martin Heidegger sobre a essência da poesia em Hölderlin.

Palavras-chave: Literaturas de língua portuguesa. Mar. Silêncio. Poesia. Sagrado.

Résumé: Cette étude propose d'analyser, à partir de référents poétiques comme la mer et le silence, et à travers une approche comparative, les liens existants entre les vers de trois poètes de langue portugaise à savoir Cecília Meireles, Sophia de Mello Breyner Andresen et Glória de Sant'Anna.

Les articulations entre la dimension du sacré et de la spiritualité nourris par les aspects symboliques de la mer et du silence révèlent une complicité entre les poètes.

Comme base de ces lectures dialogiques, ont été utilisées: les thèses du théoricien Michel Collot sur le référent poétique; la conception phénoménologique de Gaston Bachelard sur l’imaginaire matériel et dynamique de l'eau (s), et les interprétations de Martin Heidegger sur l'essence de la poésie de Hölderlin.

Mots-clés: Littératures de langue portugaise. Mer. Silence. Poésie. Sacré. 
L'appel de l'eau reclame en quelque sorte un don total, un don intime. L'eau veut un habitant. Elle appelle comme une patrie.

Bachelard (1997, p. 221)

\section{INTRODUÇÃO}

O "apelo" da água referido por Gaston Bachelard (1997) pode constituir um ponto de partida no percurso deste trabalho, em que se propõe uma reflexão dialógica da dimensão de sagrado e de espiritualidade potenciada pelos caminhos simbólicos do mar e do silêncio, nas obras poéticas de Cecília Meireles, Sophia de Mello Breyner Andresen e Glória de Sant'Anna.

No caso das três autoras de língua portuguesa, representativas de diálogos poéticos, temáticos e históricos entre o Brasil, Portugal e Moçambique, o "apelo" do mar - matéria física e imaginária - é o denominador comum, através do qual navegam as poetas.

O mar, enquanto matéria física (fisicamente navegável) e imaginária (onírica), porque as três poetas adequaram, de certa forma, as respetivas viagens biográficas às suas poéticas.

Em 1934, Cecília fez pela primeira vez a travessia do Atlântico rumo a Portugal, terra dos seus antepassados. A ligação da poeta à cultura e literatura portuguesas,

1 Apesar dos estudos de Bachelard se centrarem sobretudo nas imagens produzidas a partir das águas doces, os mesmos não invalidam o paralelismo com as águas do mar. 
"salpicadas de mar", não se limita ao legado familiar moldado por caraterísticas insulares, rico em memórias envoltas em mistério, misticismo e profundidade; órfã aos três anos de idade, Cecília é educada no Rio de Janeiro, pela avó materna de origem Açoriana (DE MELLO, 2012)2.

Também, Nelly Novaes Coelho (2001) refere que na década dos anos vinte, Cecília entra pela mão de seu marido, o artista plástico Correia Dias, em contato com o movimento poético em Portugal e, consequentemente, com Fernando Pessoa.

A propósito da forma algo inusitada como a escritora toma conhecimento da Mensagem de Pessoa, aquando da sua primeira viagem a Lisboa, descreve Novaes Coelho:

Nessa viagem, viveu um episódio curioso: marcara um encontro com Fernando Pessoa, na Brasileira do Chiado, pois já conhecia sua poesia e desejava conhecê-lo pessoalmente. Esperou-o durante duas horas, mas Fernando Pessoa não apareceu. Ao voltar ao hotel, Cecília encontrou um livro do poeta, com o pedido de desculpas pelo não comparecimento. Motivo: o horóscopo, feito pela manhã, indicava que ambos não deviam se encontrar. O livro era a Mensagem, que acabara de ser publicado e também o único publicado em vida do poeta. Desse episódio, conclui-se que a primeira pessoa a ler esse livro no Brasil, foi Cecília Meireles. (COELHO, 2001, p. 12, grifo do autor)

2 Veja-se a propósito da influência dos Açores na escrita meireliana, o texto crítico $A$ memória dos Açores na escrita de Cecília Meireles de Ana Maria Lisboa de Mello (2012). 
A viagem iniciática a Lisboa representa um marco, dado que, em 1939, a poeta publica o livro Viagem, o primeiro de uma trilogia dedicada ao mar. Seguem-se Vaga Música (1942) e Mar Absoluto e Outros Poemas (1945). Alguns dos poemas contidos nessas obras foram analisados, neste estudo.

Acima, mencionou-se o curioso episódio do (des)encontro de Fernando Pessoa com Cecília Meireles, porque não parece descabido o diálogo entre as obras acima referidas e a Mensagem do poeta português.

À semelhança de Cecília, Sophia (admiradora confessa da poeta brasileira) contruiu uma poética do mar adaptada às suas próprias vivências. Citando Carlos Ceia: "O mar de Sophia é fundado na liberdade de navegação, mas o Domínio marítimo onde a navegação poética é possível começa por ser confinado à Granja, ao Norte de Portugal, ao Atlântico e, depois de Livro Sexto, ao Algarve, ao Mediterrâneo e ao mar Egeu" (CEIA, 1996, p. 61-62).

A presença do mar na vida de Sophia foi uma constante, das férias da infância na Granja, praia de águas frias do Atlântico, passando pela descoberta do Algarve (Grutas da praia de D. Ana), nos anos sessenta (uma espécie de Mediterrâneo "a fingir"), até às viagens reais à Grécia (a primeira em 1963), parece indissociável essa osmose entre 
biografia e obra. Daí a poeta ter afirmado, numa entrevista a Virgílio de Lemos: "Eu estou sempre a falar do mar que é a coisa de que mais gosto" 3 .

Neste estudo, privilegiaram-se poemas dos livros contidos nos três tomos da obra poética de Sophia: Poesia (1944), Dia do Mar (1947), Coral (1950), Livro Sexto (1962), Geografia (1967), Dual (1972), O Nome das Coisas (1977) e Ilhas (1989).

Glória de Sant'Anna, embora nascida em Lisboa, partiu em 1951 para a antiga colónia portuguesa, Moçambique. Após ter feito uma viagem de barco, a poeta e o marido chegaram até a llha de Moçambique, de onde se deslocaram inicialmente para a província de Nampula e depois em Porto Amélia (hoje Pemba) onde permaneceu até 1972. Os dois últimos anos da sua permanência em Moçambique passouos na localidade de Vila Pery (hoje Chimoio), onde viveu até 1974, até retornar a Portugal (SPINUZZA, 2019).

Uma vez mais, se pretende demonstrar que o percurso geográfico marítimo das autoras impeliria à viagem poética, pois também os versos da autora moçambicana encontraram nos elementos naturais, sobretudo aquáticos, o reservatório da sua inspiração.

3 Carlos Ceia referindo-se à entrevista de Sophia ao poeta Virgílio de Lemos, publicada em Revista Oceanos, n. 4, julho, 1990. 
Do prefácio da antologia poética Amaranto (SANT'ANNA, 1988), obra onde estão contidos os poemas à frente analisados e/ou comentados, dos livros Distância (1951), Música Ausente (1954), Livro de Água (1961), Poemas do Tempo Agreste (1964), Um Denso Azul Silêncio (1965), A Escuna Angra (1966-1968) e Desde que o Mundo e 32 Poemas de Intervalo (1972), replicamos as palavras de Eugénio Lisboa: “O mar assume, na poética de Glória de Sant'Anna, o valor simbólico que milenariamente se lhe tem atribuído: a fonte de tudo, da vida, da purificação, da regeneração e da morte" (LISBOA apud SANT'ANNA, 1988, p. 22).

Para analisarmos e compreendermos as conexões entre as poéticas das três autoras visíveis nas temáticas e ritmos afins é necessário olharmos para o mar como se de uma janela se tratasse; se por um lado, o mar como espaço aberto representa o horizonte infinito, por outro, funciona como espelho, pois reflete o ânimo do sujeito lírico. Este movimento ambivalente entre natureza e Ser, entre coisa e palavra (ou a ausência dela), acompanha a metapoesia das autoras, muito próximo de uma ontologia do Ser. Dado a extensão do tema, este estudo centra-se, maioritariamente, na função retórica do mar como motivo e símbolo de metamorfose, de infinito, de eternidade, de Absoluto e de silêncio (num espaço sem 
coordenadas geográficas, e num tempo indefinido, portanto, intemporal) potenciando, assim, as dimensões de sagrado e de espiritualidade. Interessa analisar, particularmente, de que forma o mar, que constitui topos primordial nas poéticas das três autoras, evolui e se deixa viajar/vogar oniricamente (por ele, através dele, e em profundidade) convertendose em referentes poéticos sem fim, como fonte infinita da poesia. Um mar poético por excelência comum a Cecília, Sophia e Glória, que está sempre além do que dele se diz; por isso, se configura como um "mar sem fundo", um "mar sem fim" e "secreto" por nunca revelar tudo - um mar que reflete também a solidão e o silêncio abismal do sujeito poético, outras vezes, ponte de encontro com o outro temáticas igualmente partilhadas pelas poetas. A sacralidade "do silêncio azul do fundo do mar", muitas vezes relacionado com o mar como sepulcro, foi também alvo de atenção.

Através um conjunto de textos selecionados, procurou-se analisar de que maneira os universos imaginários/poéticos construídos nos horizontes do mar e do silêncio (des)velam dimensões de sagrado e de espiritualidade.

A perspetiva fenomenológica da referência do texto poético como desdobramento de uma realidade que se metamorfoseia constantemente, dependendo da 
consciência do sujeito em relação ao objeto, foi analisada pelo poeta e pesquisador francês Michel Collot (1989). Segundo o teórico, o referente do poema é, pois, um universo imaginário ou uma visão subjetiva do mundo que pode ser redefinida, mediante a perceção do sujeito lírico. Nas palavras de Collot, replicadas de Lefebvre, a poesia é, assim, uma espécie de reservatório contendo a totalidade das experiências que temos do objeto (COLLOT, 1989, p. 176) ${ }^{4}$.

Ecoando o acima referido, creio que nas poéticas fundadas a partir do horizonte marítimo, como as abordadas neste trabalho, o mar apela à criação funcionando como matéria moldável e dinâmica da imaginação, tal como preconizado por Bachelard. (1997, p. 1-3).

Esse "apelo" inicial da criação poética, coincidente com o primeiro momento da experiência poética, é referido por Collot que o designa, precisamente, de L'appel (1989, p. 156161), ou seja, o momento em que o sujeito lírico procura responder ao vazio ou branco da folha.

O objeto exterior, no caso o horizonte marítimo enquanto estrutura espacial aberta, não é sempre igual a si mesmo - ou uma coisa particular passível de se identificar - não podendo ser encarado sob o modo da objetividade.

4 Do original: "La poésie nous invite donc à redefinir le référent, que l’on peut concevoir comme une sorte de réservoir contenant la totalité des expériences que nous avons de l'objet" (COLLOT, 1989, p. 176). 
A invenção poética procura responder a essa metamorfose da realidade. O poeta é sensível a esse devir, pelo qual o mundo, a todo o instante, se revela outro.

O horizonte infinito como estrutura espacial transportase, assim, do sujeito para o texto.

\section{O MAR COMO MOTIVO E SÍMBOLO DE METAMORFOSE, DE INFINITO, DE ETERNIDADE E DE ABSOLUTO - A (RE)UNIÃO DO SER COM O SAGRADO}

O mar constitui tema e símbolo ${ }^{5}$ maior da poética ceciliana nos três livros de sua fase madura: Viagem (1939), Vaga Música (1942) e Mar Absoluto (1945).

No poema "Mar Absoluto", do livro de igual nome, no primeiro verso, o sujeito lírico lembra que "Foi desde sempre o mar" remetendo para o caráter iniciático e criador do elemento líquido (MEIRELES, 1945, p. 9-13).

Retomando as conceções de Gaston Bachelard, em L'eau et les rêves, a água é vista como um elemento transitório ligado a um tipo de destino que se metamorfoseia incessantemente ${ }^{6}$. Mais à frente, o filósofo menciona a capacidade de a(s) água(s), através dos seus reflexos,

\footnotetext{
5 Entenda-se "símbolo", na esteira de Mircea Eliade (1979), que o concebe revelador de uma realidade inacessível aos outros meios de conhecimento, auxiliador, portanto da tarefa reveladora do ato poético.

6 Do original: "Léau est aussi un type de destin, non plus seulement le vain destin des images fuyantes, le vain destin d'un rêve qui ne s'achève pas, mais un destin essentiel qui métamorphose sans cesse la substance de l'être"' (BACHELARD, 1997, p. 8).
} 
duplicar o mundo e as coisas ${ }^{7}$. A água é, assim, uma realidade poética completa.

Atente-se aos versos abaixo, que espelham como o sujeito lírico recorre à água informe para dar forma e contornos às imagens oníricas:

Mar Absoluto

O mar é só mar, desprovido de apegos, matando-se e recuperando-se, correndo como um touro azul por sua própria sombra, e arremetendo com bravura contra ninguém, e sendo depois a pura sombra de si mesmo, por si mesmo vencido. É o seu grande exercício.

Não precisa do destino fixo da terra, ele que, ao mesmo tempo, é o dançarino e a sua dança.

Tem um reino de metamorfose, para experiência:

seu corpo é o seu próprio jogo, e sua eternidade lúdica não apenas gratuita: mas perfeita. (MEIRELES, 1945, p. 9-13)

O mar metamorfoseia-se em "touro azul", sendo "o executor e o objeto da própria ação"8 - "é o dançarino e a sua dança", por conseguinte, eterno.

7 Do original: “[...] l'eau, par ses reflets, double le monde, double les choses" (BACHELARD, 1997, p. 68).

8 Veja-se Camila Marchioro (2017), no ensaio "Caminhos do mar em Cecília Meireles". 
O poema de Sophia Andresen (1991a), "A Vaga", que faz parte do Livro Sexto, Obra Poética II, p. 104, dialoga com o poema de Cecília Meireles, "Mar Absoluto", pois expõe também as constantes metamorfoses do mar, enquanto topos simbólico, caraterizando-o como um objeto sempre diferente de si mesmo nas diversas experiências do eu-lírico. O mar é comparado e metamorfoseado em diversos seres - "toiro", "cavalgada", "cavaleiro", "mulher", "bailarina" dependendo da perceção do sujeito poético: "Como toiro arremete / Mas sacode a crina / Como cavalgada // Seu próprio cavalo / Como cavaleiro / Força e chicoteia / Porém é mulher / Deitada na areia / Ou é bailarina / Que sem pés passeia"(ANDRESEN 1991a).

O mar ao ser, simultaneamente, cavalo e cavaleiro é, uma vez mais, o executor e o objeto da própria ação. Esta "dança [eterna] do Ser" em Sophia (BARBOSA, 2019, grifo nosso) ${ }^{9}$ ou o "mar como reino de metamorfose" em Cecília revelam a capacidade de transmutação das imagens imaginadas pelo ser poético, no espaço (ilimitado) e no tempo (intemporal); imagens que remetem para uma herança clássica ovidiana ${ }^{10}$

9 Veja-se Márcia Barbosa (2019), no ensaio "A poesia e o sagrado em Sophia de M.B. Andresen e em Cecília Meireles", replica a expressão "dança do ser", a partir de um dos versos de Sophia do poema "O Minotauro" (Dual), em que o sujeito lírico descreve o que significa a "dança do ser" - o ser que "Sem cessar se busca e se perde se desune e se reúne/ E esta é a dança do ser" (ANDRESEN, 1999, p. 148).

10 Veja-se em As Metamorfoses, o episódio do rapto de Europa, no qual o poeta romano Ovídio narra a fábula da transformação de Júpiter num manso touro, a fim de seduzir a 
(OVIDE, 1966). A capacidade de metamorfose dos seres, no caso através da(s) água(s) do mar, aproxima o poeta dos deuses (os únicos com o poder de metamorfose), assim, conferindo ao mar poético uma primeira aproximação à dimensão do sagrado.

Márcia Barbosa (2019) no seu ensaio crítico "A poesia e o sagrado em Sophia de M.B. Andresen e em Cecília Meireles" estuda as relações entre poesia e sagrado nas obras poéticas das autoras portuguesa e brasileira e afere que a poesia e o sagrado apresentam uma estrutura semelhante que os aproxima, ideia com a qual comungo e a que voltarei adiante, quando abordar a sacralidade do silêncio.

O desejo de união do ser humano com o sagrado revelase também na poesia de Glória de Sant'Anna. O poema "Marinha", que faz parte do Livro de Água (1988), indicanos o desejo do eu-lírico se fundir ao mar, numa espécie de osmose - "Por sobre a água / se alonga a minha mágoa. // (Que denso é o mar / e tão cinzento). // Por entre as algas / escorrem minhas lágrimas. (Que duro é o mar e tão azul)" (SANT'ANNA, 1988, p. 92). O sujeito poético filtra

princesa fenícia Europa, levando-a a subir em suas costas. Uma vez atingido o seu propósito, a princesa (filha de Agenor e irmã de Cadmo) é levada no dorso do deus-animal, através das ondas do oceano, até à llha de Creta. Uma ilha onde o deus-animal pudesse viver com a sua amada. Assim, deixaram a Ásia e passaram ao continente vizinho que naquela altura ainda não tinha nome. Veio a chamar-se Europa, em honra da princesa - versão cosmogónica segundo a mitologia greco-romana para o nascimento do continente europeu. 
os elementos naturais aquáticos - "água" "mar", "algas" neles espelhando o seu ânimo; as águas do mar mudam de cor; o mar torna-se "denso" e "cinzento" absorvendo a dor, mágoa e solidão do sujeito lírico, tal como refere Bachelard: "a imaginação material assume uma sensibilidade tão aguda, tão dolorosa, que pode abranger todas as dores do poeta" (1997, p. 90).

A identificação do sujeito poético com o mar (e outros elementos naturais) gera um movimento de dispersão, o que Spinuzza (2017) designa de "sujeito estilhaçado" no mundo à sua volta, levando-o a desejar projetar-se no infinito. É no infinito da imensidão do mar eterno, na fusão do eu-lírico ao mar, que a poesia de Glória de Sant'Anna encontra o Absoluto (divino). Leiam-se os versos do poema "Projecção" no Livro Distância (SANT'ANNA, 1988, p. 35): “Que há entre mim e ti de humano / e verdadeiro? // Meu coração inteiro / no fundo do oceano." Os últimos versos conferem a imagem do fundo do mar como local de sepulcro sagrado.

Quer Glória de Sant'Anna quer Cecília Meireles elegeram a permeabilidade e fluídez da água como símbolo poético para a espiritualidade. O mar, elemento retórico, concentra em si a manifestação do Absoluto, como criador de vida, destruidor (morte) e restaurador (purificador). A água é 
usada para dar forma ao informe exprimindo a fluídez e os contornos imprecisos do Absoluto (MARCHIORO, 2017, p. 7).

Embora seja na obra Mar Absoluto que o mar ceciliano surje como tema e símbolo maior, os "caminhos do mar" da escrita meireliana nascem com a obra Viagem.

É do livro Viagem o poema "Anunciação" (MEIRELES, 2006, p. 15) que, aos poucos, se (des)vela a viagem imaginária do eu-lírico em busca de si próprio navegando através de um mar de pensamentos embalados por um tom filosófico e introspetivo, triste e melancólico, transmitindo as palavras a preocupação com a fugacidade do tempo, não raras vezes, impregnadas de subtil cadência musical.

Nos primeiros versos "TOCA essa música de sêda frouxa e trêmula, / que apenas embala a noite e balança as estrêlas noutro mar" apercebemo-nos de um outro mar (diferente do existencial e terrestre) que embala a noite. Refere Bachelard (1997, p. 177-179) que "dos quatro elementos, somente a água pode embalar".

Nos versos, "Do fundo da escuridão nascem vagos navios de ouro / com as mãos de esquecidos corpos quási desmanchados no vento. // Toca essa música de sêda, entre areias e nuvens e espumas", denota-se uma poesia marcada por elementos não sólidos, pois ao mar são acrescidas imagens aéreas e etéreas, 
como a própria "música" (cujas notas se propagam através do ar), "noite", "estrelas", "vento", "nuvens" e "espumas"; a escolha dos elementos aéreos e etéreos pode ser explicada pela simbologia das imagens metafóricas. O vento corresponde ao desassossego do sujeito lírico; a noite à solidão abismal; as "nuvens" e "espumas" pela sua eteridade representam a fugacidade da vida, e, de certa forma, simbolizam também o "casamento" entre o mar e o céu.

Os últimos versos do poema "Anunciação" - "E a memória de tudo desmanchará suas dunas desertas / e em navios novos homens eternos navegarão." - talvez possam ser justificados no sentido do sujeito poético acalentar a crença de superação da finitude humana na Terra através da vastidão do mar eterno, "proporcionando as águas a salvação na eternidade" (ELIADE, 1979, p. 149).

Voltado para o mar, o sujeito lírico constrói caminhos imaginários entre céu e mar em busca de si próprio e vê na poesia a possibilidade de eternidade. Fazendo eco das palavras de Bachelard (1997, p. 179): “É perto da água, é sobre a água que se aprende a vogar sobre as nuvens, a nadar no céu"; e, continua o filósofo: "a água nos convida à viagem imaginária." ${ }^{11}$.

11 Do original: “C'est près de l'eau, c'est sur l'eau qu'on apprend à voguer sur les nuages, à nager dans le ciel. [...] L'eau nous invite au voyage imaginaire" (BACHELARD, 1997, p.179). 
O poema "Beira Mar" do livro Mar Absoluto e Outros Poemas (MEIRELES, 1945, p. 72) revela toda a força simbólica do mar como representação do Absoluto (invisível, sem substância e eterno) possibilitando a (re)união do Ser com o sagrado. Atente-se nos versos: "porque isto é mal de família, / ser de areia, de água, de ilha..." o sujeito poético alude às suas origens insulares; refere não pertencer à Terra, mas estar no limbo entre Terra e mar $^{12}$, dado que a areia protagoniza essa união, sendo também efémera (desaparece/ desliza entre os dedos); Cecília afirma "ser de água", dado as caraterísticas do elemento líquido (fluídez e sem forma); "ser de ilha", pelo simbolismo iniciático da criação e, também, de isolamento/solidão. A poeta adapta as caraterísticas do mar à sua própria jornada/viagem existencial e imaginária, pois "até sem barco navega / quem para o mar foi fadada." // Deus te proteja, Cecília, / que tudo é mar - e mais nada." Assim, conclui espelhando nestes últimos versos a crença em Deus e no Absoluto divino, simbolicamente representado pelo mar, (re)unindo-se com o sagrado.

A demanda de Sophia Andresen pelo Absoluto percorre toda a sua obra poética, uma poesia fundada na observação

12 Aquilo a que Sophia de Mello Breyner Andresen, referindo-se à poesia de Cecília Meireles, designaria de "suspensa entre reinos divididos". A este respeito veja-se o ensaio de Márcia Barbosa "A Poesia e o Sagrado em Sophia de Mello Breyner Andresen e Cecília Meireles" (2019, p. 74). 
do mar, a partir da praia. Carlos Ceia (1996, p. 64) refere "uma poesia da navegação onírica de quem prefere contemplar o mar a percorrer realmente as suas águas", o que, a meu ver, não invalida o inicialmente proposto neste estudo, ou seja, uma certa adaptação dos percursos geográficos vivenciados às viagens poéticas. Tal como em Cecília, o mar é, também em Sophia, o caminho marítimo de ligação (retorno) à sua infância. É através do mar que Sophia evoca poeticamente o mundo clássico grego e a memória da história das navegações portuguesas. É contemplando o horizonte no mar que a poeta encontra o infinito.

No poema "Mar Sonoro" que faz parte do livro Dia do Mar, Obra Poética I, o sujeto poético encontra-se sozinho, à beira-mar, e deseja oniricamemte que o infinito cristalize o seu sonho: "Mar sonoro, mar sem fundo, mar sem fim. / A tua beleza aumenta quando estamos sós / E tão fundo intimamente a tua voz / Segue o mais secreto bailar do meu sonho" (ANDRESEN, 1991b, p. 84).

No poema "Inicial" (ANDRESEN, 1999, p. 134), do livro Dual, Obra Poética III, o sujeito poético, associa o nascimento de Afrodite ("nascida da espuma") ${ }^{13}$ ao mar de poeta - "O mar

13 Saliente-se o diálogo com O nascimento de Afrodite/ Vénus das Metamorfoses de Ovídio e com a representação através da pintura Renascentista de Sandro Botticelli. A demanda pela harmonia e perfeição são também caraterísticas da poesia sophiana, à qual não foi indiferente o mundo clássico grego. 
azul e branco... / Onde sou a mim mesma devolvida / Em sal espuma e concha regressada / À praia inicial da minha vida." Pressente-se a reverência da poeta à sacralidade do azul e branco do mar, como espaço de tranquilidade, paz e Luz. A dimensão reflexiva na poesia andreseniana, tal como reflete a "dança do ser", almeja a concentração, a unidade essencial. É através de um mar Absoluto (que reduz a voz poética à condição ínfima de Ser) que Sophia procura alcançar a forma plena da comunicação - pelo poema - "Mesmo que eu morra o poema encontrará / Uma praia onde quebrar as suas ondas" - "O Poema", Livro Sexto (ANDRESEN, 1991a, p. 120).

\section{A SACRALIDADE DO SILÊNCIO E A MISSÃO DO POETA EM DIZER O INDIZÍVEL}

Ecoando o atrás referido, relativamente ao pensamento de Michel Collot acerca do referente poético que pode ser constantemente redefinido, afere-se que daí resulta a dificuldade da escrita poética em "dizer" um horizonte "sem fim"; a impossibilidade em transmitir através de palavras algo que não se deixa "dizer" (ou representar na totalidade). O referente que o poema procura é, assim, inacessível pois trata-se de um horizonte de invisibilidade e indizibilidade (inalcançável), sendo a linguagem poética uma tensão permanente entre o desejo de uma proximidade absoluta e a sua impossibilidade. Face a este 
insucesso, e replicando o pensamento de Francis Ponge ${ }^{14}$, Collot propõe uma outra abordagem da verdade do Ser, que estaria presente não no Verbo (palavra), mas por sua ausência, o que aproxima a estrutura da poesia à estrutura do sagrado ${ }^{15}$. Logo, havendo "um referente que não se deixa dizer", o poema terá de encontrar um outro horizonte de origem silenciosa. Segundo Collot "o horizonte último do poema é o silêncio"16 (COLLOT, 1989, p. 184). Somente o poeta, através do poema, é capaz de escutar o silêncio; nas palavras de Collot: "o poema comunica-se com o silêncio interior ao mundo e diz mais do que as palavras poderiam dizer"17 (COLLOT,1989, p. 184). O colocar-se à escuta do silêncio pelo poeta, segundo o teórico francês, constitui o segundo momento da experiência poética designando-a de “espera” (L'attente) (COLLOT, 1989, p. 161-166).

Também George Steiner nas suas reflexões sobre $O$ poeta e o silêncio afirma:

14 Segundo Francis Ponge: "O poema muitas vezes se desenvolve numa ausência sentida, da qual traz uma nova presença [...] não é o ausente que se desenvolve, mas uma realidade incrível que se constitui como uma resposta ao que não está - uma correspondência" (STEINMETZ apud PONGE, 1990, p. 219).

15 Poder-se-á estabelecer um paralelo com o fenómeno da transubstanciação, tal como acontece com a estrutura do sagrado. Este tema, ainda que aplicado à estrutura dos dramas litúrgicos, é largamente analisado por Kobialka (2009) em This Is My Body Representational Practices in the Early Midle Ages.

16 Do original: "Le référent du poème ne se laisse pas dire: son horizon ultime, c'est le silence" (COLLOT,1989, p. 184).

17 Do original: "[...] le poème comunique avec le silence intérieur au monde, il dit plus que les mots ne sauraient dire" (COLLOT, 1989, p. 184). 
[...] a linguagem tem mesmo suas fronteiras, [...] confina com três outras modalidades de manifestação - a luz, a música e o silêncio - [...] fornece prova de uma presença transcendente na estrutura do mundo. Exatamente porque não podemos ir mais longe, porque a língua nos falha [...] temos a certeza de um sentido divino que supera e envolve o nosso. (STEINER, 1988, p. 55-74)

O crítico refere que talvez sob a influência de Heidegger, e da interpretação que este fez de Hölderlin, a recente filosofia linguística francesa também atribui uma função especial e uma prestigiosa autoridade ao silêncio, conforme se tem vindo a demonstrar, neste estudo, com as teses de Michel Collot (algumas na senda de Henri Lefebvre).

Afirma ainda Steiner: "O silêncio é uma alternativa [...] nada fala mais alto do que o poema não-escrito" (1988, p. 73).

Remetendo também às conceções de Martin Heidegger e às interpretações que este fez acerca da poesia de Hölderlin (1983, p. 55-67), o filósofo evidencia o papel da poesia como condição de existência da linguagem e do mundo. Ao replicar do poeta Friedrich Hölderlin a máxima: "L'homme habite en tante que poète"18 - Heidegger assume que "o homem só habita [num sentido ontológico] junto ao mundo"; - "somos no mundo" e "só onde há linguagem,

18 Segundo Hölderlin: "Habitar poeticamente significa, estar na presença dos deuses e ser tocado pela proximidade essencial das coisas" (HEIDEGGER, 1983, p. 62, tradução nossa). 
há mundo", assim considerando a linguagem poética, não como produto, mas como "acontecimento fundacional do Ser e da essência de todas as coisas." Por outras palavras, o Ser e a essência das coisas não se conseguem alcançar a partir no existente no mundo (palpável e visível), então devem ser criados e outorgados livremente através da palavra poética. É através da palavra que o Ser ilumina as coisas, sendo a poesia a evocação primordial do Ser e da essência de todas as coisas.

Essa é, segundo Heidegger, na esteira de Hölderlin, a missão do poeta por este ser, dentre os homens, aquele que melhor se acerca dos mistérios do Ser e do Tempo e, consequentemente, mais próximo dos deuses (sagrado).

De que forma estas conceções são passíveis de serem demonstradas nas poéticas das três autoras?

O poema de Cecília Meireles, "Solidão", que também faz parte do livro Viagem (MEIRELES, 2006, p. 30), espelha um eu-lírico à deriva e esquecido de si mesmo, navegando sem coordenadas geográficas nem temporais, num mar "negro, mais eterno / mais terrível, mais profundo", empreendendo uma viagem errática em busca do desconhecido - segundo Collot (1989, p. 166-169), este constitui o terceiro momento da experiência poética 
designando-a de "errância" (L'errance), sendo ela própria como a existência, uma totalização sempre incompleta. ${ }^{19}$

Nos versos seguintes, "Este rugido das águas / é uma tristeza sem forma" - rugido que, a meu ver, pode ser encarado como um grito no silêncio da solidão e tristeza do sujeito poético; a dor da sua solidão é abismal e, não podendo ser transmitida por palavras, o poeta remetese ao silêncio das "Imensas noites de inverno / com frias montanhas mudas." Devido às limitações da linguagem e não encontrando palavras que o signifiquem (palavras incapazes de reproduzir a ideia do real), o eu-lírico toma consciência dessa falha e "substitui-a" pelo silêncio para expressar o indizível ${ }^{20:}$ "A noite fecha seus lábios / - terra e céu - guardado nome".

A sacralidade do silêncio é espelhada pela metáfora da noite e do fundo do mar, quer pela imagem da profundidade das águas (pela simbologia de infinito) quer pelo motivo do naufrágio (pela simbologia do "naufrágio" como perda da identidade do sujeito poético), qualquer um dos recursos retóricos bastante frequentes na poética meireliana. As

19 Do original: “L'expérience poétique est donc, comme l'existence elle-même, une totalisation toujours inachevée" (COLLOT, 1989, p. 169).

20 Veja-se a esse propósito a afirmação de Eduardo Lourenço acerca do enigma da poesia: "Só o criador sabe que no lugar de uma forma não havia outra forma e que o dicionário é impotente para os filólogos quanto mais para os poetas" (LOURENÇO, 1987, p. 29). 
mortes ocorridas na família da autora (desde a infância até à morte do primeiro marido) impelem-na para o horizonte de uma praia solitária, funcionando a "metáfora da profundidade do mar" como espelho do passado de um sujeito poético triste e nostálgico.

O mar, primordialmente, provedor de vida, é paradoxalmente, topos para a meditação metafísica da morte (sepulcro sagrado) ${ }^{21}$. É exemplo o poema "Naufrágio Antigo" do livro Vaga Música: "Inglesinha de olhos tênues, / corpo e vestido desfeitos / em águas solenes // inglesinha do veleiro, / com tranças de metro e meio / embaraçando os peixes" (MEIRELES, 2001, p. 43-46).

Curiosamente, "vaga" poderá assumir diversas conotações, remetendo para onda marítima, para as brumas da memória ou mesmo para o campo musical; conforme acima referido, uma das caraterísticas da lírica meireliana é a musicalidade subjacente às palavras (o embalar das ondas do mar poético de Cecília; a canção; o murmúrio ou a palavra quase silenciada).

Também de Vaga Música é o poema "Canção quase inquieta" (MEIRELES, 1994, p. 187). Os versos espelham a condição da poeta dividida entre dois reinos, céu e mar:

21 Bachelard em L'eau et les rêves, relaciona as águas profundas à melancolia (1997, p. 10); as águas silenciosas, sombrias, dormentes e insondáveis são propícias à meditação da morte (1997, p. 96). 
"De um lado, a eterna estrela / e do outro a vaga incerta"; um sujeito lírico disperso "entre estandartes do vento" e "sepulcros fechados"; interiormente estilhaçado e à deriva de si mesmo, mas que procura nessa viagem errática em busca do desconhecido, um sentido para a vida, através da (re)união com o Absoluto (divino) - "E eu me partindo, dentro de mim" / para estar no mesmo momento de ambos os lados. // Se existe a tua Figura / se és o sentido do mundo // Fazedor da minha vida, / Entende a minha canção! / Tem pena do meu murmúrio, / reúne-me em tua mão! // Que sou gota de mercúrio, dividida, / desmanchada pelo chão...".

No poema "Motivo" do livro Viagem (MEIRELES, 2006, p. 13), a autora assume a missão do poeta: "Eu canto porque o instante existe / e a minha vida está completa. / Não sou alegre nem sou triste: / sou poeta." A poeta canta porque canto e poesia convivem desde o mistério da esfinge. Cecília des(vela) o enigma da sua poesia: "porque o instante existe" e, como nos transmite Eduardo Lourenço (1987, p. 35), “o Instante nunca principia" e, por isso, "não pode ter fim". Assim é a poesia de Cecília Meireles, uma canção que nunca principia nem termina, eternamente embalada pelas ondas do mar. De modo subtil, desde a experiência de Viagem, passando por Vaga Música, até chegar a Mar Absoluto, 
as águas do mar poético meireliano, incessantemente, assumem diversas formas até desaguarem no mar Absoluto, símbolo maior do Absoluto (divino) - a essência de toda a existência, de vida e de morte.

Em Sophia Andresen, a sacralidade do silêncio manifestase, maioritariamente, pelo azul do mar e pela luminosidade da madrugada. O mar inaugural de Sophia é o mar clássico dos gregos onde, desde Homero, se privilegia a experiência poética da aurora. Nas palavras de José Pedro Serra (ANDRESEN, 2019) 22: "é a luminosa madrugada que vai outorgar identidade às coisas e aos seres." É a vitória da luz do cosmos (mundo organizado) que se sobrepõe ao caos (noite obscura), conforme se viu, anteriormente, no poema "Inicial" onde o mar se avistava azul e branco. Estas caraterísticas encontramo-las, também, nos poemas "O Minotauro" (Dual), "Enquanto Longe Divagas" (O Nome das Coisas) e "O Sol O Muro O Mar (Ilhas), livros presentes na Obra Poética III (ANDRESEN, 1999).

\author{
O Minotauro \\ Em Creta \\ Onde o Minotauro reina \\ Banhei-me no mar
}

E o mar de Creta por dentro é todo azul

22 A esse propósito veja-se o prefácio de José Pedro Serra a O Nu na Antiguidade Clássica. (ANDRESEN, 2019). 
Oferenda incrível de primordial alegria Onde o sombrio Minotauro navega

\section{Em Creta}

Os muros de tijolo da cidade minoica São feitos de barro amassado com algas E quando me virei para trás da minha sombra Vi que era azul o sol que tocava o meu ombro Em Creta onde o Minotauro reina atravessei a vaga De olhos abertos inteiramente acordada Sem drogas e sem filtro Só vinho bebido em frente da solenidade das coisas Porque pertenço à raça daqueles que percorrem o labirinto Sem jamais perderem o fio de linho da palavra (ANDRESEN, 1999, p. 147-149)

A apetência de Sophia pela claridade é, igualmente, referida por Carlos Ceia: “A presença da luz renascida num mar absolutamente azul, como são todos os mares de Sophia [...] apesar do ambiente de melancolia. Invariavelmente, todos os livros sagrados de todas as civilizações ensinam que a luz será sempre o último destino depois da dissolução pela morte" (CEIA, 1996, p. 64).

Assim, se compreende o simbolismo das "duas conchas na mão" do capitão do poema "Navio Naufragado", do livro Dia do Mar, Obra Poética I - no qual transparece a crença do 
eu-lírico de que a morte no mar pressupõe uma ressurreição - "É um esqueleto branco o capitão, / Branco como as areias, / Tem duas conchas na mão / Tem algas em vez de veias / E uma medusa em vez de coração" (ANDRESEN, 1991b, p. 111).

À semelhança do fundo do mar meireliano, o de Sophia é, neste poema, também um "mundo silencioso que não atinge / A agitação das ondas." - "Fundo do Mar" (ANDRESEN, 1991b, p. 50), do livro Poesia, Obra Poética I. E, insondável por nunca revelar tudo. No poema "Da Transparência" (ANDRESEN, 1999, p. 88), do livro Geografia, Obra Poética III, o sujeito poético lamenta não haver corais nem búzios no fundo do mar da alma: "No fundo do mar da nossa alma não há corais nem búzios / Mas sufocado sonho / E não sabemos bem que coisa são os sonhos / Condutores silenciosos canto surdo" - no mar existencial os corais causam espanto pela sua cor (apelam ao sentido visual) e os búzios (emitem um som semelhante ao "marulhar" apelando, portanto, ao sentido auditivo); pode haver alguma sinestesia intencional se atribuirmos um significado duplo à palavra coral, que remete quer para um ambiente marítimo quer para a sonoridade dos cânticos, o que ecoa a sinestesia da palavra "vaga" em Cecília Meireles. No mar interior do sujeito poético apenas se afigura um "canto surdo". A "canção murmúrio" de Cecília 
ou o "canto surdo" de Sophia refletem a vontade de dizer o indizível aos ouvidos mais atentos. É essa a missão do poeta: abolir a fronteira entre as palavras e as coisas através do seu canto $^{23}$. Para tal, o poeta vê para além da linha desenhada do horizonte em sua espessura de realidade; tem o poder oracular de escutar o insinuado ou sussurrado: "Como um rumor do mar dentro de um búzio / O divino sussurra no universo / Algo emerge: primordial projecto." - do poema "Como o rumor" no livro O Nome das Coisas, Obra Poética III (ANDRESEN, 1999, p. 184).

No poema "Ó Poesia - Quanto te pedi" do livro Coral, Obra Poética I (ANDRESEN, 1991b, p. 223), o sujeito poético invoca a poesia para dela exigir a recomposição da aliança entre o homem (Ser) e as coisas. De acordo com a poética andreseniana essa aliança teria sido corrompida - "Quando o rei foi morto e o reino dividido."; a forma de conceder identidade às coisas consiste em chamá-las pelo seu nome "Ó poesia - quanto te pedi!", fazendo com que apareçam em sua própria distância (tal como na estrutura do sagrado, o caso da transubstanciação, atrás referido). Parece, pois, que para Sophia, a verdade está no poema, em não se perder "o fio de linho da palavra".

23 A este respeito refere George Steiner: "O poeta cria à perigosa semelhança dos deuses. Seu canto constrói cidades; suas palavras têm aquele poder que, acima de todos, os deuses negariam ao homem, o poder de conferir vida duradoura" (1988, p. 56). 
Na poesia andreseniana, o poema delineia-se como a única possibilidade de se alcançar a felicidade. Felicidade que não pode ser vista nem ouvida, através da alma (não tem "corais" nem "búzios"), mas através da palavra poética. Trata-se de uma poesia-pensamento, com uma fronteira muito ténue com a filosofia Aristotélica e, onde ecoam muito das conceções de Heidegger sobre Hölderlin, dado poetizar a essência da poesia.

A poesia de Glória de Sant'Anna prima por ser uma escrita na água (mar, oceano, vagas, algas, corais, pérolas marinhas, sal, ilha, chuva, lago, lágrima, lua) ... "e a lua é de água." Poema "Nocturno", Livro de Água, Amaranto (SANT'ANNA, 1988, p. 71): "Dentro da madrugada clara / o vento é de vidro e a lua é de água / e por entre as arestas das casas / o mar se alonga e arfa. // (tão grande e tão denso o antigo silêncio ......."

Para lá da janela existencial se estende o horizonte infinito marítimo de Glória. O mar nas suas imagens desdobradas é local de vida e morte, de purificação e regeneração. 0 elemento aquático devido à sua fluidez (que "não se deixa prender") ajudará o sujeito poético a construir a imagem de um secretismo transparente que (des)vela o objeto: "o azul secreto da água" - "Poema do Mar", 32 Poemas de Intervalo, 
Amaranto (SANT'ANNA, 1988, p. 190). O azul secreto do mar servirá também de metáfora ao "denso azul silêncio", nomeando o livro de igual nome. Conforme enfatiza Spinuzza: "A imagem do silêncio aliada à da impenetrabilidade e da fugacidade da água leva à identificação do sujeito com o elemento aquático" (2017, p. 46).

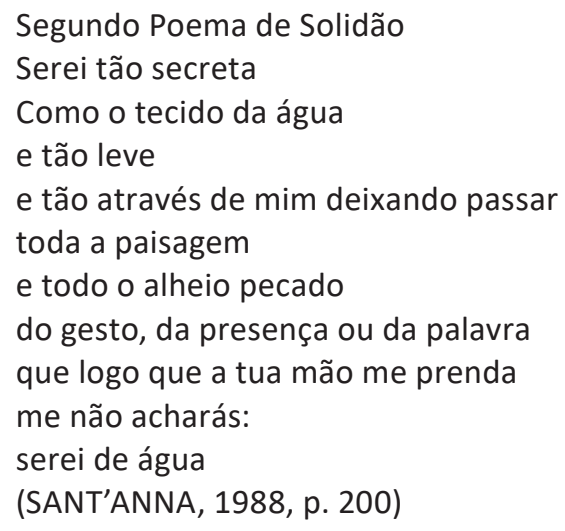

Trata-se de uma poética introspetiva, de vertente lírica e intimista em que o sujeito filtra o mundo exterior (elementos naturais, sobretudo aquáticos e aéreos) com o intuito de (des)velar o que há de mais íntimo e secreto em si. O mar infinito e profundo como elemento retórico para a solidão e o silêncio possibilitam, a meu ver, visões dialógicas com a poética de Cecília Meireles.

Tal como nas poéticas de Cecília e de Sophia, o mar poético de Glória pode simbolizar topos de morte, de 
túmulo sagrado, mas igualmente possibilitar a purificação e a regeneração.

Atente-se no poema "Recado" do livro Música Ausente, título que memora Vaga Música de Cecília Meireles. Pede o sujeito poético em "Recado": "Se eu morrer longe / sepultame no mar / dentro das algas ignorantes / e lúcidas. // Cobre o meu rosto de palavras / antigas / e de música. ........ // Eu vogarei sob as estrelas / com pálidas luzes entre os cílios / e pequenos caramujos / entrarão nos meus ouvidos" (SANT'ANNA, 1988, p. 57). Se por um lado, como referimos, ressoam nos versos de "Recado" a intertextualidade e a musicalidade com a poética meireliana em Vaga Música la "canção murmúrio") por outro, ouvimos o "canto surdo" de Sophia - "No fundo do mar da nossa alma não há corais nem búzios" (ANDRESEN, 1999, p. 88) - porque segundo Platão, a alma não vê nem ouve. Mas o eu-lírico de Glória, através da capacidade purificadora e regeneradora do mar, permite a visão ("pálidas luzes entre os cílios") e a audição ("pequenos caramujos / entrarão nos meus ouvidos") na eternidade. A eternização da vida pelo mar ganha, assim, uma dimensão sagrada. Mais uma vez, só o poeta tem essa capacidade de "cantar o poema" como quiser, isto é, de apreensão da essência das coisas - pela palavra. Quando 
as palavras são incapazes de reprodução da ideia do real, estas dão lugar ao silêncio.

O poema "Afirmação", do livro Um Denso Azul Silêncio reflete a indagação da poeta acerca da essência das coisas (da própria existência): “A essência das coisas é senti-las / tão densas e tão claras, / que não possam conter-se por completo / nas palavras. // A essência das coisas é nutri-las / tão de alegria e mágoa, / que o silêncio se ajusta à sua forma / sem mais nada" (SANT'ANNA, 1988, p. 126).

No poema "Motivo", do livro Poemas do Tempo Agreste (SANT'ANNA, 1988, p. 97), muito próximo do poema “Motivo" de Cecília Meireles (Viagem), Glória de Sant'Anna identifica-se com a poeta brasileira ao falar também da essência da poesia. Como refere Almiro Lobo ${ }^{24}$, a propósito do poema "Motivo" de Glória:

"[...] o poema serve para falar sobre a vida e a própria arte: é sempre angústia que transborda", "como um rebento novo que se desdobra" e "como uma lágrima que se solta." Como angústia pode ser cantado de amor, de ódio, de roda e "como rebento novo que se desdobra" pode ser cantado ao sol, de água, de sombra. Como lágrima pode ser cantado como quiser porque "há sempre uma palavra que nos esconda." (LOBO, 2020, p. 181-186, grifos do autor)

24 Veja-se o ensaio de Almiro Lobo: “O não-dito de Glória de Sant’Anna” (2020, p. 181-186). 
Lobo (2020) ressalva dois aspetos importantes da poética de Glória de Sant'Anna, a liberdade de criação poética, e a possibilidade da palavra ocultar o sujeito, por outras palavras, o secretismo como marca de água da sua poesia e a subtileza de dizer o "não-dito".

\section{CONSIDERAÇÕES FINAIS}

Este estudo transversal às obras poéticas de Cecília Meireles, Sophia Andresen e Glória de Sant'Anna pretendeu demostrar que as três autoras se aproximam e tecem visões dialógicas entre si.

Partem de um mar primordial (cosmogónico) propiciador de um horizonte infinito, permitindo o desdobramento incessante de imagens, na sua função retórica como motivo e símbolo de metamorfose e de eternidade. Um mar poético, isento de coordenadas geográficas e temporais, portanto, à primeira vista, não coincidente com o mar existencial das respetivas trajetórias biográficas, mas a ele adaptado: mar poético por excelência, onde os sujeitos poéticos navegam erraticamente à procura, não raras vezes, de si mesmos.

A vertente lírica e intimista, plena de tristeza, melancolia e solidão, em que o sujeito poético filtra o mundo exterior para (des)velar o que mais íntimo e secreto habita em si, parece acentuar-se em Cecília Meireles e Glória de Sant'Anna. Os 
sujeitos líricos, em movimentos de dispersão, mergulham no mar profundo do seu interior; estes, na impossibilidade de transmitir por palavras os seus sentimentos e pensamentos, fecham-se sobre si mesmos, preservando o silêncio - assim, resultando a ausência de luz, metaforizada pela noite (o próprio mar pode adquirir tons escuros) e de voz (pela solidão e pelo silêncio). Trata-se de uma viagem feita de silêncio e solidão, corporizadas pelo mar Absoluto (divino), que revelará a dimensão de espiritualidade e de sagrado, proporcionando as águas profundas a salvação na eternidade.

Por outro lado, o porto de onde se inicia a viagem poética de Sophia desenha-se no horizonte primordial das viagens dos argonautas, privilegiando a luz e a claridade. É um mar mítico, pintado de azul e branco (lustral), no qual se "mergulha de olhos abertos "para se "reconhecer no fundo do mar os dias primordiais" (CEIA, 1996, p. 76). Trata-se de uma viagem através de um mar em expansão, criador de um mapa metáfora na construção da própria poesia (de que é exemplo o Livro Navegações, Obra Poética III).

Mesmo quando topos de morte, "o azul do mar é [sempre] perfeito" - veja-se o poema "Barco" in Coral (ANDRESEN, 1991b, p. 236, grifo nosso) e a esperança renasce da luz onde "o sol impregna de oiro a espuma." - veja-se o poema 
"Tristão e Isolda" in Dia do Mar (ANDRESEN, 1991b, p. 108); é, portanto, no azul do mar e na vivência peculiar da solaridade que se materializa a demanda da imortalidade e a revelação da palavra poética que eterniza a existência do Ser no mundo.

A poesia como a arte do Ser adquire em Sophia contornos estéticos e éticos: o poema é a possibilidade de se alcançar a felicidade e a verdade; como se todas as coisas estivessem imbuídas de "divino", competindo ao poeta revelar essa sacralidade.

No início deste trabalho fez-se referência ao possível diálogo entre as obras cecilianas da trilogia do mar, Viagem, Vaga Música e Mar Absoluto com a Mensagem de Fernando Pessoa. Creio que o mar constitui também o filão indelével de uma dimensão pessoana comum às obras das três autoras.

Em Cecília Meireles, nas obras sobre o mar aludidas, desvela-se um eu-lírico que não se cinge a uma só imagem, mas a múltiplas, como um ser caleidoscópio. Podemos ver nessa multiplicidade laivos de modernidade dos poetas portugueses dos primeiros anos do século XX, como Pessoa.

Em Sophia Andresen, os poemas de evocação ao poeta, nomeadamente, "Em Hydra, evocando Fernando Pessoa" 
em Dual, (1999, p. 144-146) e "Cíclades" em O Nome das Coisas (1999, p. 175-178) partem de uma vivência insular, aquando da viagem da poeta às ilhas do Egeu. A poeta recria a experiência de navegar pelo Mediterrâneo e associa esse peregrinar às viagens interiores do criador da Mensagem, identificando-o, simultaneamente, à errância de Ulisses/ Odysseus. Curiosamente, a imagem da multiplicidade/divisão das ilhas impele, por associação, a imagem da heteronímia25.

Também os poemas de A Escuna Angra (SANT'ANNA, 1988, p. 141-153) retoma o filão épico dos navegadores portugueses até à baía de Pemba, onde foi fundada a colónia. De acordo com Giulia Spinuzza (2017, p. 35) “[...] o texto que evoca as navegações do Infante Dom Henrique de Avis e dos seus homens, ecoa os versos da Mensagem de Fernando Pessoa".

Em suma, o peregrinar poético sobre o mundo e a vida, tendo o mar como horizonte, é, no fundo, comum às autoras, pois as três poetizaram a essência das coisas e da própria poesia como revelação do Ser. Afinal, como enuncia Octavio Paz: "a poesia revela este mundo e cria outro", e "o poema não é somente uma forma literária, mas o lugar de encontro entre a poesia e o homem" (2018, p. 14).

25 A esse propósito veja-se o ensaio Sophia na Grécia, evocando Fernando Pessoa (HÖRSTER; SILVA, 2017). 


\section{REFERÊNCIAS}

ANDRESEN, Sophia de Mello Breyner. Obra Poética II. Lisboa: Caminho, 1991a.

ANDRESEN, Sophia de Mello Breyner. Obra Poética I. 2. ed. Lisboa: Caminho, 1991b.

ANDRESEN, Sophia de Mello Breyner. Obra Poética III. 4. ed. Lisboa: Caminho, 1999.

ANDRESEN, Sophia de Mello Breyner. O Nu na Antiguidade Clássica. Lisboa: Assírio \& Alvim, 2019.

BACHELARD, Gaston. L'eau et les rêves-essai sur límagination de la matière. 25. ed. Paris: Librarie José Corti, 1997.

BARBOSA, Márcia Helena Saldanha. A poesia e o sagrado em Sophia de Mello Breyner Andresen e Cecília Meireles. Letras de Hoje, [S.I.], v. 54, n. 1, p. 74-84, 2019. Disponível em: https://revistaseletronicas.pucrs.br/ojs/ index.php/fale/article/view/33827. Acesso em: 26 de Maio de 2021.

CEIA, Carlos. Iniciação aos mistérios da poesia de Sophia de Mello Breyner Andresen. Lisboa: Vega, 1996.

COELHO, Nelly Novaes. Cecília Meireles: vida e obra. Revista do CESP Universidade de São Paulo, [S. I.], v. 21, n. 28/29, 2001.

COLLOT, Michel. La poésie moderne et la structure d'horizon. Paris: puf écriture, 1989.

DE MELLO, Ana Maria Lisboa. A memória dos Açores na escrita de Cecília Meireles. Letras de Hoje, [S. I.], v. 47, n. 4, p. 381-386, 2012. Disponível em: https://revistaseletronicas.pucrs.br/ojs/index.php/fale/article/ view/12771. Acesso em: 26 de maio de 2021.

ELIADE, Mircea. Imagens e símbolos. Lisboa: Arcádia, S.A.R.L., 1979. HEIDEGGER, Martin. Interpretaciones sobre la poesía de Hölderlin. Barcelona: Editorial Ariel, S.A., 1983.

HÖRSTER, Maria António; SILVA, Maria de Fátima. Sophia na Grécia, evocando Fernando Pessoa. Nuntius Antiquus, [S.I.], v. 13, n. 1, p. 59-84, 2017. Disponível em: 26 de maio de 2021. 
https://periodicos.ufmg.br/index.php/nuntius_antiquus/article/ view/17117. Acesso em: 26 de maio de 2021.

KOBIALKA, Michal. The Regularis Concordia: "Qui facit veritatem venit ad lucem". This Is My Body: Representational Practices in the Early Middle Ages, [S.I.]: The University of Michigan Press, p. 35-99, 2009. Available at: https://www.press.umich.edu/16103/this_is_my_body. Accessed on: 26th May 2021.

LOBO, Almiro. O não-dito de Glória de Sant'Anna. In: LOFORTE, Luís; MATOS, Edmundo Galiza. Quando o Silêncio é Sujeito: Um tributo a Glória de Sant'Anna. Pemba: Pemba \& Sêwi Editores, 2020.

LOURENÇO, Eduardo. Tempo e Poesia: À volta da literatura. Lisboa: Relógio D’Água, 1987.

MARCHIORO, Camila. Caminhos do mar em Cecília Meireles. Interfaces, [S.I.], v. 8, n. agosto, p. 63-81, 2017.

MEIRELES, Cecília. Mar absoluto e outros poemas. Porto Alegre: Livraria do Globo, 1945.

MEIRELES, Cecília. Poesia completa. Rio de Janeiro: Nova Aguilar, 1994.

MEIRELES, Cecília. Antologia poética. 3. ed. [S.I.]: Editora Nova Fronteira, 2001. MEIRELES, Cecília. Viagem. eBooksBras ed. [S.I: s.n.]. Disponível em: www.ebooksbrasil.org. Acesso em: 26 de maio de 2021.

OVIDE. Les métamorphoses. Paris: Garnier-Flammarion, 1966.

PAZ, Octavio. El arco y la lira. El poema. La revelación poética. Poesía e historia. Ciudad de México, 2018.

SANT'ANNA, Glória de. Amaranto - Poesia 1951-1983. Lisboa: Imprensa Nacional Casa da Moeda, 1988.

SPINUZZA, Giulia. Poéticas do Mar e do Amor na Poesia Moçambicana: Glória de Sant'Anna e Eduardo White. 2017. UL-Faculdade de Letras, [S.I.], 2017. Disponível em: https://repositorio.ul.pt/handle/10451/27995. Acesso em: 26 de maio de 2021.

SPINUZZA, Giulia. A poesia de Glória de San'Anna: um roteiro de leitura dos primeiros livros. [S.I.], v. 11, n. 21, Janeiro, 2019. Disponível em: 
https://revistas.ufrj.br/index.php/mulemba/article/view/31269. Acesso em: 26 de maio de 2021.

STEINER, George. Linguagem e Silêncio-Ensaios sobre a crise da palavra. São Paulo: Companhia das Letras, 1988.

Ana Paula Perdiz de Crato Fogaça Mestre (Faculdade de Letras da Universidade de Lisboa - FLUL). Doutoranda (FLUL). https://www.cienciavitae.pt//pt/E919-E6B9-929A http://orcid.org/0000-0003-3377-6430 ana.fogaxa@gmail.com 